\title{
Analysis of Learning Process in Early Childhood Age 4-5 Years Old
}

\author{
Pramono \\ Faculty of Education, State University of Malang, Indonesia \\ pramono_paud76@yahoo.com
}

\author{
Nurhasan \\ Graduate Student, State University of Surabaya, Indonesia \\ nurhasan@yahoo.com
}

\author{
Nining Widyah Kusnanik \\ Graduate Student, State University of Surabaya, Indonesia \\ nining.widyah@gmail.com
}

\begin{abstract}
This research was conducted to find out the analysis of learning process needs in early childhood at age 4 to 5 five years in Malang city and Malang regency. This research uses qualitative research method. The sample used was by purposive sampling technique based on geographical location, 2 PAUD is located in downtown area, 2 PAUD is in suburb area, and 2 PAUD is in remote area. The number of PAUD educators are 30. Based on the results of interviewing problems faced by the mother of PAUD educator can be concluded that: (1) problem planning faced include: selecting the method according to indicator 93.3\%; developing learning media 93.3\%; developing learning media 93.3\%; developing indicator $83.9 \%$; (5) Determining the material according to indicator $83.9 \%$; (2) implementation: opening no problem; core experiencing problems in inspirational learning $83.3 \%$; closing is no problem; and (3) the assessment of the problem: determining the assessment instrument in accordance with the domain that will be in the value of $83.3 \%$; conducting judgment according to procedure 93.3\%; analyzing the appraisal data $93.3 \%$; summarizing the result of $93.3 \%$ assessment; reporting the results of the assessment $93.3 \%$. Based on the results of the analysis of the needs of the learning process in early childhood at the institution of early childhood aged $4-5$ years is still needed learning model of basic motion activities, activities to develop creativity and activities to develop prosocial behavior based on cognitive theory, humanistic theory, constructivist theory, 2014 and Candy 137 years 2014.
\end{abstract}

Keywords: learning process, early childhood

\section{INTRODUCTION}

Each a child is unique, a child will develop his own reaction pattern to the stimulation has been experienced, and he will develop according to his each tempo and speed. Thus, the speed of a child's development is not always in line with his friends and chronological age. The development occuring in children includes behavioral development and development of basic skills. The development of behavior includes the development of religious and moral values, emotional social development, and independence. The development of religious values is a development to recognize the religion adopted and familiarize themselves to worship. The development of moral values is a development to understand noble behavior, differentiate good and bad behavior. In the development of children's behavior is given the habit of applying good behavior everyday life.

The development of basic skills is a learning activity that is prepared to improve the ability and creativity of children which includes physical and motor development, cognitive, language, social emotional. Cognitive development is a development to have general knowledge, shape patterns, colors, size, knowledge of numbers, symbols of numbers and letters. Emotional social development is a development for the right way to get along with others. Physical and motor development is a development to have a rough and smooth motor skills and can grow optimally. The existence of early childhood education is expected to help optimize the development of their various potential.

For a child, learning is everything done when the child is playing. A play is a vehicle for learning and working naturally for children. An early child enjoys paying attention to the activities of making sounds, feeling, and tasting. A rich and stimulating environment can enhance child's learning abilities. The environment will provide a lot to cultivate a child's interests and encourage him to learn and play actively. A child will be easier to learn if the experience of learning experiences in line with the level of mental maturity or according to its development. Excessive experience will frighten the child, otherwise, a minimal experience will bore the child. By these basic assumptions, the teacher has a special view about the child.

An educator / a teacher is no longer demanding that the child to be someone according to what he wants, but the teacher respects the child as he is. Accepting child's circumstances without neglecting regularity and discipline in complying with the rules. An educator / a teacher should give more opportunities for child to be more free to explore the environment.

\section{METHODS}

A qualitative approach is used in this research because the data and information are more explanatory. The qualitative research is as a human instrument, functioning to set the focus of research, selecting informants as data, do data collection, assessing data quality, data analysis, interpreting data to make conclusions on the findings, (Sugiyono, 2007: 60). In qualitative research, everything that will be searched for the object of research is not a clear and certain problem, the expected source of expected results is not clear yet.

Technique of data collecting is done by scientific condition, using primary data (direct observation in field), and collecting technique in field such as closed interview, check list and documentation. The samples are by purposive sampling technique 
based on geographical location, 2 PAUD in downtown area, 2 PAUD in suburb area, and 2 PAUD in remote area. There are 30 PAUD educators.

\section{RESULT AND DISCUSSION}

The activity of learning analysis at early child is done based on result of interview and charging check list in learning process. From this activity is obtained data as follows. What method or learning model that you give, some statements that often appear are summarized as follows (Table 1). The problems are often faced by PAUD educators after being percentage, shown in Table 2.

Table 1

Learning Step

\begin{tabular}{|c|c|c|}
\hline No & Learning Step & Teacher Activities (Describing) \\
\hline 1 & Opening & $\begin{array}{l}\text { - The teacher makes conditions the students in a circle. } \\
\text { - The teacher greets } \\
\text { - Ssk the students' condition } \\
\text { - Starting daily prayer } \\
\text { traditiong from the transition until the core activity to invite students for singing, claping, playing } \\
\text { - The teacher tells the topic, what will do. } \\
\text { - The teacher explains thet game and the idea in it. } \\
\text { The teacher invites scientific play }\end{array}$ \\
\hline 2 & Core activity & $\begin{array}{l}\text { - The teacher asks the students to walk around observing, let the students to ask, tell about the theme. } \\
\text { - After completing together scientific play, the teacher directs the students to choose the game } \\
\text { according to their interest. } \\
\text { - (previously the teachers prepare some density games }\end{array}$ \\
\hline 3 & Closing & $\begin{array}{l}\text { - The teacher codes that the game is over, the students start cleaning up. } \\
\text { - The teacher asks the students to make a circle to communicate their feelings and what games have just } \\
\text { been done. } \\
\text { - The teacher asks the students to pray after the play and explain the game will be performed tomorrow. }\end{array}$ \\
\hline
\end{tabular}

Table 2

The Problems of Learning Implementation

\begin{tabular}{|c|c|c|c|}
\hline Learning Implementation & Encountered Problems & $\begin{array}{c}\text { Number of } \\
\text { Percentage Answer }\end{array}$ & Percentage \\
\hline \multirow[t]{7}{*}{ Planing } & 1. Understanding a core competence & 5 & $16.7 \%$ \\
\hline & 2. Understanding a basic competence & 5 & $16.7 \%$ \\
\hline & 3. Developing indicator & 25 & $83.3 \%$ \\
\hline & 4. Determine the material according to the indicator & 25 & $83.9 \%$ \\
\hline & 5. Selecting methods that match the indicator & 28 & $93.3 \%$ \\
\hline & 6. Developing learning media & 28 & $93.3 \%$ \\
\hline & 7. Develop assessment procedures & 28 & $93.3 \%$ \\
\hline \multirow{13}{*}{ Implementation } & Opening: Preparing students psychically and physically to perf & various learning activi & \\
\hline & 1. Apperception (connecting with previous learning & 15 & $50 \%$ \\
\hline & 2. Explain the purpose of learning & 10 & $33 \%$ \\
\hline & 3. Explain the benefits of learning & 15 & $50 \%$ \\
\hline & $\begin{array}{l}\text { 4. Explain the activities to be carried out. } \\
\text { Core }\end{array}$ & 15 & $50 \%$ \\
\hline & 1. Interactive Learning & 8 & $26.7 \%$ \\
\hline & 2. Inspirative Learning & 25 & $83.3 \%$ \\
\hline & 3. Enjoyable Learning & 10 & $33.3 \%$ \\
\hline & 4. Contextual Learning & 14 & $46.7 \%$ \\
\hline & 5. Child-centered Learning & 2 & $6.7 \%$ \\
\hline & Closing & & \\
\hline & $\begin{array}{l}\text { 1. Efforts to re-explore the students' play experience that } \\
\text { has been done in one day }\end{array}$ & 15 & $50 \%$ \\
\hline & $\begin{array}{l}\text { 2. Encourage the studentsto follow the next learning } \\
\text { activity. }\end{array}$ & 15 & $50 \%$ \\
\hline \multirow[t]{6}{*}{ Assessment } & 1. Understanding the aspect to be assessed & 15 & $50 \%$ \\
\hline & $\begin{array}{l}\text { 2. Determine the assessment instrument in accordance with } \\
\text { the domain that will be assessted }\end{array}$ & 25 & $83.3 \%$ \\
\hline & 3. Conduct judgment according to procedure & 25 & $83.3 \%$ \\
\hline & 4. Analyze assessment data & 28 & $93.3 \%$ \\
\hline & 5. Concluding assessment result & 28 & $93.3 \%$ \\
\hline & 6. Reporting assessment result & 28 & $93.3 \%$ \\
\hline
\end{tabular}

Based on the problem data faced by PAUD educators can be concluded: (1) the planning of problems encountered include: selecting methods that correspond to indicators $93.3 \%$; developing learning media 93.3\%; developing learning media 93.3\%; developing indicator $83.9 \%$; determining the material according to indicator $83.9 \%$. (2) implementation: opening is no problem; the core problems in the inspirational learning is $83.3 \%$; closing is no problem; and (3) the problem assessment: determine the assessment instrument in accordance with the domain that will be assessted $83.3 \%$; carrying out the evaluation according to procedure $93.3 \%$; analyzing the assessment data 93.3\%; concluding the assessment result 93.3\%; and reporting the assessment results $93.3 \%$. The method or teaching model that you give or 
some statements that often appear concluded as follows:

$$
\begin{aligned}
& \text { - Learning model used is by center model. } \\
& \text { - Methods of assignment, demonstration and projects } \\
& \text { are often used to develop students' creativity in } \\
& \text { exploring. }
\end{aligned}
$$

Activities of rough motor stimulation of children aged 4-5 years with the learning model that have been done by PAUD educators or some statements that often appear concluded as follows:

- To stimulate the students' rough motor, the teacher uses the demonstration method through the game of musical instruments, (singing while dancing, exercising and song, percussion music game, (drum band) where everything is adjusted with the theme

Emotional social activities of children aged 4-5 years with a learning model has been done by PAUD educators or some statements that often appear concluded as follows:

- Giving the students freedom in having games.

- In role playing centers, the students are given the opportunity to play a micro and macro role.

Activities of self-responsibility stimulation for students aged 4-5 years with a learning model has been done or some statements that often appear concluded as follows:

Giving confidence by smoothing toys. Thus, it can train

the students to have a sense of responsibility.

Activities of rough prosocial behavioral stimulation for students aged 4-5 years with a learning model has been done or some statements that often appear concluded as follows:

- Asking the students to make rules of the game, to train the students obeying the rules made by themselves.

- Saal recalling, the students will learn to appreciate their friends' work.

- Asking the students to work together.

Activities of creativity stimulation of children aged 4-5 years with learning model have been done or statements that often appear concluded as follows:

- In the block center, the teacher asks the students to create the shape of the building.

- In the art center, the teacher gives the students the freedom to express themselves through painting, coloring, and drawing.
From the results of field observations with open interviews and checklist of preliminary studies above to obtain information on the learning implementation in early child aged 4-5 years, then to continue further research. The most ideal educator / teacher is a person who has the both well-educated and trained professional competence, and has a lot of experience in his field. The education and training is not only formal education, but also pedagogic competence that is mastering educational strategy, has knowledge about ways to educate, as well as make the design activities (for 1 year, 6 months, weekly, and daily) and knowledge about health, able to organize the class.

Educators / Teachers have to have professional competency, and know how to deal with various child problems, start from handling quarrel among children until activating study group. A rich experience and personality competence means having a good attitude, and good behavior that can be delivered to the child. The attitudes and values will be reflected in the way teachers teach in the classroom. In addition to the expertise and experience of teachers, other factors that need attention are the sincere love for children, interested in children development, and able to develop the potential possessed in children, warm to children in behaving and play together with them.

Early childhood is a crucial time for the growth of the child to receive a enough good stimulus. It is directed and pushed to their growth and development level. Early childhood development is important to organize in helping to lay the groundwork for developing attitudes, knowledge, skills and creativity within in both the family and institution of Early Childhood Education (PAUD) before entering basic education as follows.

Introduction Recent guidelines from the United Kingdom (UK) recommend that preschool children (35 years) should participate in at least $180 \mathrm{~min}$ of physical activity (PA) of any intensity (i.e. light, moderate, vigorous) each day for maintenance of a healthy weight, as well as improved bone and cardiovascular health. The early years are a critical period to promote and establish positive health behaviours, with levels of PA tracking from early to mid-dle childhood. Understanding factors that may influence the PA behaviours of young children is essential for the development of effective interventions (Lawrencer,et al. 2015).

Motor development is considered an important factor in children's overall health. In spite of its significance, a common understanding of the latent construct of motor behavior underlying assessment is lacking. Different hypotheses and concepts have been introduced to explain motor behavior. One popular hypothesis is the classic General Motor Ability Hypothesis which states that numerous motor abilities are highly related within a person and form a single general motor ability (Till, et al. 2016).

The above opinions can be concluded that early childhood education is very important to be implemented in helping to make foundation for developing the attitude, knowledge, skills and creativity through the provision of educational stimuli 
to assist growth and physical and spiritual development, so that, the children have readiness in entering further education organized in one integrated learning program

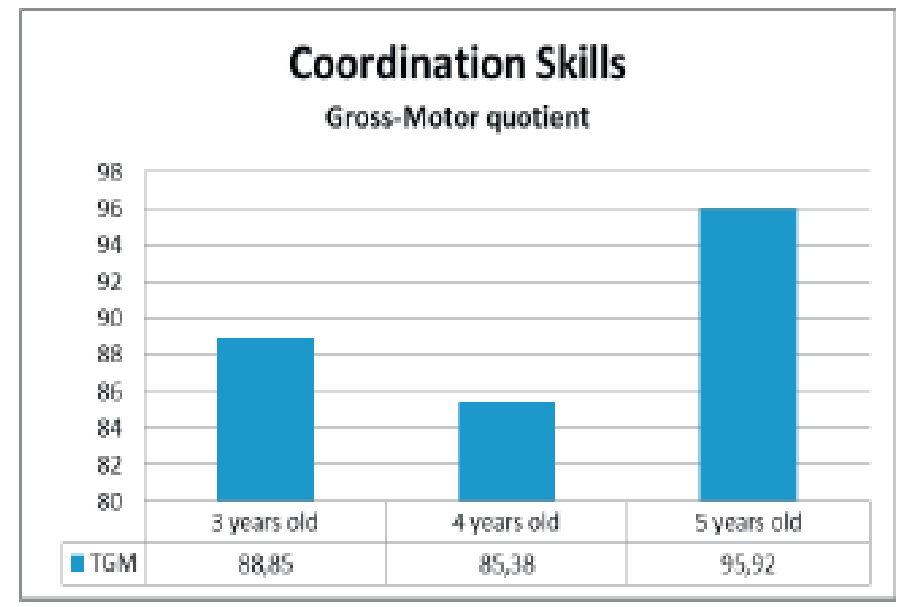

Figure 1

Test of Gross motor skills (All Sample) (Mariarosaria, et. al. 2015)

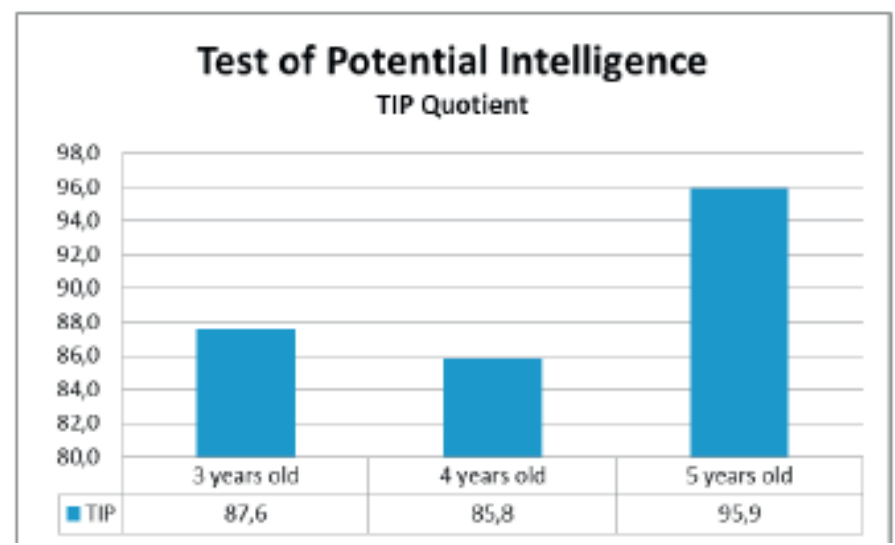

Figure 2

Test of Potential Intelligence (All Sample) (Mariarosaria, et. al. 2015)

In the research and development of learning model of Creative, Enjoyable, Experience, Innovative, Play to increase movement activities, creativity, and prosocial behavior in early childhood, which aims at providing stimulus education to help the growth and development of children. If at this early age is not given stimulus to help stimulation of motoric physic development, the motoric physic development will interfered for the future.

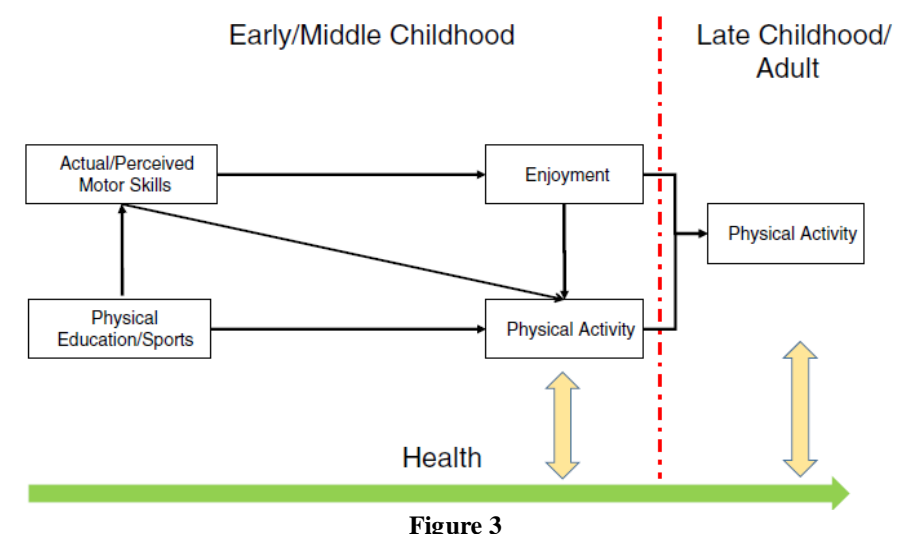

Conceptual Model Delineating Potential Direct and Indirect Pathways of Motor Competence on Child/Adult Physical Activity (Paul, et.al. 2015) 
PAUD Educators / Teachers are consistent and flexible, humorous and agile in dealing with the needs, interests and abilities of children. The educators / teachers also have social competence, interact with parents, among fellow educators / teachers, children and the community.

Based on the result of need analysis from association of early childhood teachers in Malang city, Malang regency and 6 early childhood education institutions show that the learning process is not executed well as expected, this is indicated from interview result of need analysis as follows: (1) some problems are still encountered in making learning planning such as: developing indicators; determining indicator material; developing indicators; developing assessment procedures; (2) in the implementation of learning problems encountered include: opening apperception (linking with previous learning), explain the objectives; core inspirational learning, contextual learning; closing encourage children to follow the next lesson; (3) in the assessment implementation includes: to understand the domain to be assessed; to analyze the assessment data; to report the results of the assessment; (4) the method or model of learning used is still less clear in average; (5) to provide rough motor stimulation of 4-5 years old children are still given the opportunity to explore running freely, climbing trees, kicking the ball; (6) to provide social stimulation emotional aged 4-5 years is still less clear; (7) to provide self-sense stimulation 4-5 years old children is with learning model of parenthing and guidance program; (8) to stimulate prosocial behavior of children aged 4-5 years is with a traditional game model; and (9) to stimulate the creativity of 4-5 year olds is with a model of grain-seeking for meronce (stringing grains).

\section{CONCLUSION}

Description of the need analysis of the learning process in early childhood aged 4 -5 years in PAUD institutions is still needed learning model of basic motion activities, activities to develop creativity and activities to develop prosocial behavior based on coqnitive theory, humanistic theory, constructivist theory. In the 2013 curriculum of Early Childhood from Regulation of Education and Ministery number 137 year 2014 on the National Standard for Early Childhood Education groups of 4-6 years.

\section{REFERENCES}

[1] Anderson, L. W., \& Krathwohl, P. R. 2001. A Taxonomy for Learning, Teaching and Assesing: Revision of Bloom's Taxonomy of Educational Objective. New York: Longman.

[2] Arikunto, S. 2010. Prosedur Penelitian Suatu Pendekatan Praktis. Jakarta: Rineka Cipta.

[3] Bamidis, P. D., Vivas, A. B., Styliadis, C., Frantzidis, C., Klados, M., Schlee, W., Siountas, A., and Papageorgiu, S. G. 2014. A Review of Physical and Cognitive Interventions in Aging. Neuroscience and Biobehavioral Reviews, 44, 206-220 .
[4] Beaty, J. J. 2013. Observasi Perkembangan Anak Usia Dini. Jakarta : Kencana Prenadamedia.

[5] Borg, and Gall. 2003. Educational Research: An Introduction. New York and London: Longman Inc.

[6] Cameron, C. E., Brock, L. L., Murrah, W. M., Bell, L. H., Worzalla, A. L., Grissmer, D., and Morrison, F. J. 2012. Fine Motor Skills and Executive Unction Both Contribute to Kindergarten achIevement. Child Dev, 83(4): $1229-1244 . \quad$ doi: $10.1111 / \mathrm{j} .1467-$ 8624.2012.01768.x.

[7] Caterina, P., Claudia, C., Rosalba, M., Ilaria, S., Ilaria, M., Giuseppe, V., and Roberta, F. 2013. Searching for Cognitively Optimal Challenge Point in Physical Activity for Children with Typical and Atypical Motor Development. Mental Health and Physical Activity, 6, 172-180.

[8] Davis. 2009. Early Childhood Education for Sustaintability: Recommendations for Development. International Journal of Ealy Childhood, 41(2), 113120.

[9] Dean, K. S. 2014. Creative Performance, Expertise Acquisition, Individual Differences, and Developmental Antecedents: An Integrative Research Agenda. Intelligence, 45, 66-73.

[10] Dwiyogo, W. 2009. Metakognisi Guru Pendidikan Jasmani, Olahraga dan Kesehatan di Sekolah Dasar dalam Pembelajaran. Jurnal Sekolah Dasar, 18(1), 87102.

[11] Donggun, A., Song, Y., and Carr, M. 2016. A Comparison of Two Models of Creativity: Divergent Thinking and Creative Expert Performance. Personality and Individual Differences, 90, 78-84.

[12] Dziedziewicz, D., Oledzka, D., and Karwowski, M. 2013. Developing 4 to 6 Year Old Children's Figural Creativity Using. Thinking Skills and Creativity, 9, 8595.

[13] Fadlillah, M. 2012. Desain Pembelajaran PAUD. Jogjakarta: AR-RUZZ MEDIA.

[14] Farid, B., Frederik, J. A., Deconinck, S. D., Liesbeth, V., Greet, D. P., Matthieu, L., and Eva, D. 2013. The Effectiveness of a Fundamental Motor Skill Intervention in Pre-schoolers with Motor Problems Depends on Gender but not Environmental Context. Research in Developmental Disabilities, 34, 45714581.

[15] Fatma, C. K., Sami, M., and Selda, U. 2012. The Investigation Effects of Sample Pilot Study Program on Postur of Preschool Children. Procedia - Social and Behavioral Sciences, 46, 2806-2810.

[16] Fazelian, P., and Azimi, S. 2013. Creativity in Schools. Procedia - Social and Behavioral Sciences, 82, 719723.

[17] Indriana, Y., and Windarti, T. 2008. Mengembangkan Kematangan Sosial pada anak Melalui Outbond. Jurnal Sekolah Dasar, 17(2), 143 - 152.

[18] Ismail, A. 2006. Education Games: Menjadi Cerdas dan Ceria dengan Permainan Edukatif.Yogyakarta: Pilar Media.

[19] Ilaria, M., Giuseppe, V., Elena, B., Caterina, P., Nancy, G., and Aurelio, C. 2013. Assessing Locomotor Skills Development in Childhood using Wearable Inertial Sensor Devices: The Running Paradigm. Gait \& Posture, 37, 570-574.

[20] Jyrki, R., Leila, S., and Heikki, R. 2012. The Amount of Physical Activity in Finnish Day Care. Procedia Social and Behavioral Sciences, 45, 501-506.

[21] Joyce, B., and Weil, N. 2008. Model of Teaching. Yogyakarta: Pustaka Pelajar. 
[22] Kleman, P. 2008. Towards Transformation: Conception of Creativity in Higher Education. Innovation in Education and Teaching International, 4(5), 209-216.

[23] Mariarosaria, G., Cristiana, D., Nicolina, P., Filippo, G. P. 2015. Gross-motor Skills for Potential Intelligence Descriptive Study in a Kindergarten. Procedia - Social and Behavioral Sciences, 174, 3797-3804.

[24] Reppaa, G. P. 2010. The Enjoyment of Two Teaching Programs (Creative and Non-creative One) in Physical Education The Case of 4th and 6th Grade in Greek Elementary School. Procedia Social and Behavioral Sciences, 2, 2212-2216.

[25] Reza, K. A. A., Parvizi, R., Khalegh, S. J., and Bagher, H. S. 2015. Effective Design Principles in Promotion of Children's Creativity in Residential Spaces. Procedia Social and Behavioral Sciences, 202, 31-46.

[26] Runcho, M. 2004. Creativity. Annual Review of Psychology, 6(4), 650-657.

[27] Till, U., Farid, B., Floris, H., Bernd, S., Maike, T., Kristine, D. M., Jan, S., Matthieu, L. 2016. Using Rasch Modeling to Investigate the Construct of Motor Competence in Early Childhood. Psychology of Sport and Exercise, 24, 179-187.

[28] Tomoliyus. 2012. Pembuatan Alat Aktivitas Jasmani Edukatif, Kreatif dan Inovatif Berbasis Budaya dan Lingkungan Untuk Anak TK. Yogyakarta: State University of Yogyakarta.

[29] Trina, H., Megan, T., Katherine, L. D., Kylie, B, Salmon, J., Hesketh, K. D. 2014. Early Childhood Physical Activity, Sedentary Behaviors and Psychosocialwell-being: A Systematic Review. Preventive Medicine, 62, 182-192.

[30] Lawrence, F., Zoe, K., Nicola, D. R., Mareesa, V. O., Jonathan, D. F., and Gareth, S. 2015. Fundamental Movement Skills in Relation to Weekday and Weekend Physical Activity in Preschool Children. Journal of Science and Medicine in Sport, 18, 691-696.

[31] Lin, R. 2012. A Study of Curriculum Innovation Teaching and Creative Thinking for Picture Book Creation. IERI Procedia, 2, 30-35.

[32] Linda, P., Jan, P. P., and Martin, S. H. 2013. Motivation for Physical Activity in Children: A Moving Matter in Need for Study. Human Movement Science, 32, 1097-1115.

[33] Mariarosaria, G., Cristiana, D., Nicolina, P., and Filippo, G. P. 2015. Gross-motor Skills for Potential Intelligence Descriptive Study in a Kindergarten. Procedia - Social and Behavioral Sciences, 174, 37973804.

[34] Mahmuod, S., Ali, M. S., Javad, A. 2011. Effect of Selected Motor Skills on Motor Development of Both Genders Aged 5 and 6 Years Old. Procedia Social and Behavioral Sciences, 15, 1723-1725.

[35] Munandar, S. C. U. 2009. Mengembangkan akan Kreativitas Anak Sekolah. Jakarta: Gramedia.

[36] Nieven, N., \& Plomp, T. 2007. Formative Evaluation in Educational Design Reseach. Enschede: Nedherlands Institue for Curriculum Development.

[37] Nieven, N. 1999. Prototyping to Reach Product Quality. In Akker, J., (Eds)., Design Approaches and Tolls in Education an Training. Doordrecht: Kluwer Academic Publiser.

[38] Nieven, N. 2010. Formative Evaluatiuon in Education Design Reseach. In Ploom, T. N., (Eds)., An Introduction to Educational Design Research. Enschede: SLO Nedherland Institude for Curriculum Development.

[39] Paul, D. L., Robert, E. D., and Yang-Chieh, F. 2015. Early Motor Skill Competence as a Mediator of Child and Adult Physical Activity. Preventive Medicine Reports, 2, 833-838.

[40] Putra, N. 2012. Reserach and Development. Jakarta. PT Raja Grafindo Persada.

[41] Santrock. 2004. Educational Psychologi. Dallas: McGrow Hill.

[42] Soemiarti, P. 1995. Buku Ajar Pendidikan Prasekolah. Jakarta: Ministry of Education and Culture.

[43] Solso, R. L., Maclin, O. H., and Maclin, M. K. 2008. Cognitive Psychology. Boston: Pearson Education.

[44] Sugiyono. 2007. Memahami Penelitian Kualitatif. Bandung: Alfabeta.

[45] Suharman. 2011. Kreativitas Teori dan Pengembangan. Surabaya: Laros.

[46] Sujiono, Y. 2009. Konsep Dasar Pendidikan Anak Usia Dini. Jakarta: Depdiknas.

[47] Weisberg, R. W. 1993. Creativity: Beyond The Math of Genius. New York: Freeman.

[48] Yazar, T., and Arifoglu, G. 2012. A Research of Audio Visual Educational Aids on the Creativity Levels of 414 Year old Children as a Process in Primary Education. Procedia - Social and Behavioral Sciences, 51,301-306.

[49] Yildirim, A. 2010. Creativity in Early Childhood Education Program. Procedia Social and Behavioral Sciences, 9, 1561-1565.

[50] Zahra, P., Yusooff, F., Hasim, M. S. 2013. Effectiveness of Training Creativity on Preschool Students. Procedia - Social and Behavioral Sciences, 102, 643-647. 